Vol. 3, No. 1, 2021

https://doi.org/10.23939/jtbp2021.01.064

Myron Hohol, Ivan Peleshko, Alexey Petrenko, Dmytro Sydorak

\title{
ANALYSIS OF CALCULATION REGULATION METHODS IN STEEL COMBINED TRUSSES
}

\author{
Lviv Polytechnic National University, \\ Department of Building Production, \\ gogolmyron@i.ua
}

(C) Hohol M., Peleshko I., Petrenko A., Sydorak D., 2021

The article is devoted to the calculated regulation of the stress deformation state (SDS) of combined steel trusses, which allows to reduce the efforts in some sections of the structure by increasing the efforts in other and design evenly stressed structures as the most rational systems.It is shown that the calculated method of SDS regulation makes it possible to reduce steel consumption by up to $34 \%$. Four methods of calculated SDS regulation are proposed. The advantages of combined structures are given: the concentration of materials and the possibility of designing them as lowelement.

Shown in the example,that for the quantitative criterion of quality it is possible to use rationally the maximum potential energy of deformation. Dependences for calculation of the maximum potential energy of compressed, stretched and compressed-bent elements of rod bearing steel structures are given.

Key words: steel combined truss, rational designing, stress deformation state, methods of calculation regulation, completeness of stress state, quantitative quality criterion, maximum potential energy.

\section{Introduction}

Current trends in construction in Ukraine are acute problem of increasing the efficiency of steel structures, which would be competitive compared to foreign counterparts.Today the leading direction of effective metal construction is the use of light steel structures in floors and coatings for industrial, civil and agricultural purposes.One of the ways to increase the efficiency and cost-effectiveness of steel building structures coatings and floors is to develop new, more rational (with low material and laborintensive manufacturing) structural forms due to the concentration of material, low element, improvement of calculation methods, the choice of calculation models taking into account the geometric and physical nonlinearities of the system (Hohol, 2018; Ruiz-Teran et al, 2010; Shymanovskiy, 2018).

\section{Analysis of basic research and publications}

Modern process of designing rational building load-bearing structures - including trusses, engineering structures - including trusses, engineering structures is most closely associated with saving material and minimizing its volume or weight (Yuriev, 2013). One of the methods of solving this problem is the use of calculated force control in light steel combined structures in the design process, which does not require any additional material costs(Permyakov et al, 2007).This, in turn, requires the development of new calculation methods and design forms that would meet these requirements (Bendsoe et al, 2003; Hohol, 2014).The main task during the design of building structures, which is met by the engineer, is to obtain a uniform or uniformly stressed structure, in the most rational system. This can be achieved by reducing the design effort in some elements (sections) of the structure and increasing the effort in other 
elements (sections).It is established that the largest reserves of stress deformation state (SDS) control are hidden in the combined structures (sprung, cable, hanging) structures of coatings and floors, the disclosure of which by rational formation of SDS in the cross sections of the structure already at the design stage will significantly increase its efficiency and economy (Amiret al, 2016; Gogolet al, 2018).

The essence of such regulation is the rational choice of the topology of structures, the nature of the fastenings on the supports, the calculation of its geometric parameters and the stiffness characteristics of the rod elements.

The main working element of the combined structures is a stiffening beam, the metal content of which largely depends on the technical and economic performance of the entire system.It is the design conditions of the stiffening beam that make it possible to adjust the effort throughout the system.

Therefore, the problem of calculation of building structures with the calculation method of SDS regulation, including combined, should first of all be posed as a problem of their rational design. Thus, rational design is an urgent problem, the solution of which will lead to a significant economic effect.

\section{Presentation of the main research material}

The main advantage of combined structures is the concentration of materials and the ability to design them low-element (Hoholet al, 2015; Lavrinenko et al, 2019).In most steel combined structures, the bulk $(65-85 \%)$ of the mass of material is concentrated in the stiffening beam, the technical and economic indicators of the whole system largely depend on the design conditions and metal consumption.

Such systems, in turn, require the development of both a computational method of effort regulation and technological methods of its implementation (Ruiz-Teran et al, 2008).

Adjustment of forces in steel beams of continuous section is most expedient to carry out their transformation into inseparable (Hohol, 2018), that provides essential reduction of bending moments.This principle is used in combined structures. The results of their calculations give an uneven stress state along the length of the main element - stiffening beams, which is a significant difference between the reference and flight moments. This makes existing combined designs not always rational (Hohol, 2018). Equalization of moments can be achieved using the calculated regulation of SDS.

Alignment of the values of the design stresses and increase the number of design sections in the stiffening beam will reduce the cross section of the beam and increase the efficiency of such structures without additional material costs.

Consider the efficiency of formation of a continuous two-span beam from a single-span.For example, in a single-girder beam, putting in the middle of the span elastic support,you can adjust the stiffness of the elastic support so that all the extremes of the moment have the same value and are equal to $\mathrm{ql}^{2} / 48$. Reduction of the moment in the continuous beam on the average rigid support, from the value of $\mathrm{M}=\mathrm{ql}^{2} / 32$ to the value of $\mathrm{M}_{\min }=\mathrm{ql}^{2} / 48$, which is $34 \%$ less,can be achieved using calculated regulation of efforts.

We will analyze the methods of calculated regulation of SDS in the beam of rigidity of the combined system, which can be used to regulate SDS in combined trusses.

The first method of calculated adjustment of the stiffening beam of a combined system, such as a truss, is to transform (using a reinforcement system of sprung or cables) single-span articulated beam (Fig. 1) into inseparable, on intermediate elastic supports, multi-beam (Fig. 2). Features of this transformation processes are considered in (Hohol, 2018).

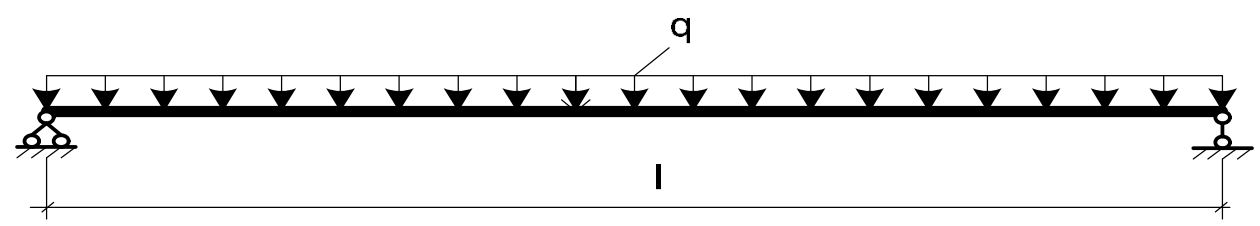

Fig. 1. Physical model of single-track hinged stiffening beams 


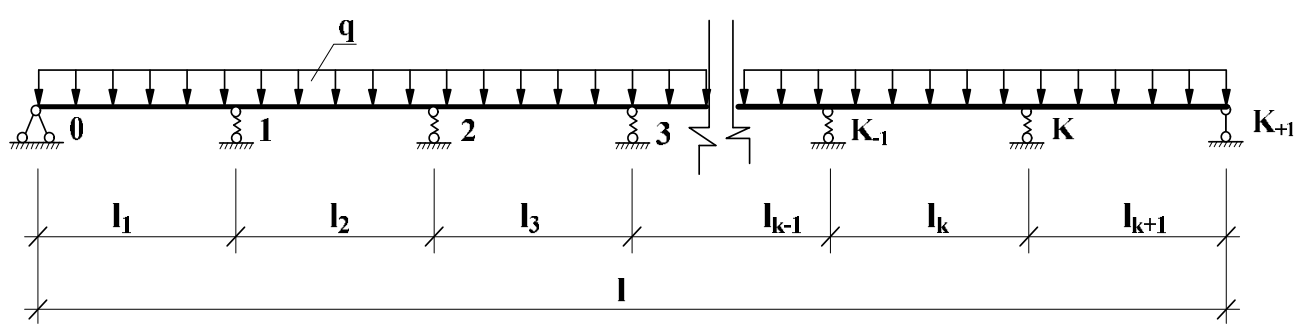

Fig. 2. Physical model of indivisible stiffening beam on intermediate elastic supports, multi-span

In (Hohol, 2018), based on the energy principles of structural mechanics, a functional dependence between the deformation energy $\mathrm{U}_{\mathrm{b}}$ during bending of an ordinary beam was obtained and the deformation energy $U$ when bending the inseparable stiffening beam on the intermediate elastic supports with equal extremum diagram $\mathrm{M}_{\mathrm{x}}$, which simulates the upper belt of combined trusses, and the number of its runs $\mathrm{n}$ (excluding the energy of the supports):

$$
U \cong \frac{U_{b}}{4,6 n^{4}}, \text { or } \lim U=\lim _{n \rightarrow \infty} \frac{U_{b}}{4,6 n^{4}}=0 .
$$

As follows from (Hohol, 2018), with increasing number of $n$ runs of the stiffening beam (corresponding to $n-1$ - the number of its reinforcements by the struts of the sprung system) to infinity,the deformation energy of such a beam is reduced to zero, ie the beam is transformed into a rigid rod on a rigid base, in which there are no bending deformations (Fig. 3).

It is established (Hohol, 2018), that the mass of the beam on two supports during its transformation into an inseparable beam on intermediate elastic supports (upper belt of combined trusses) decreases intensively with a small number of runs, ie with small values of $n$.

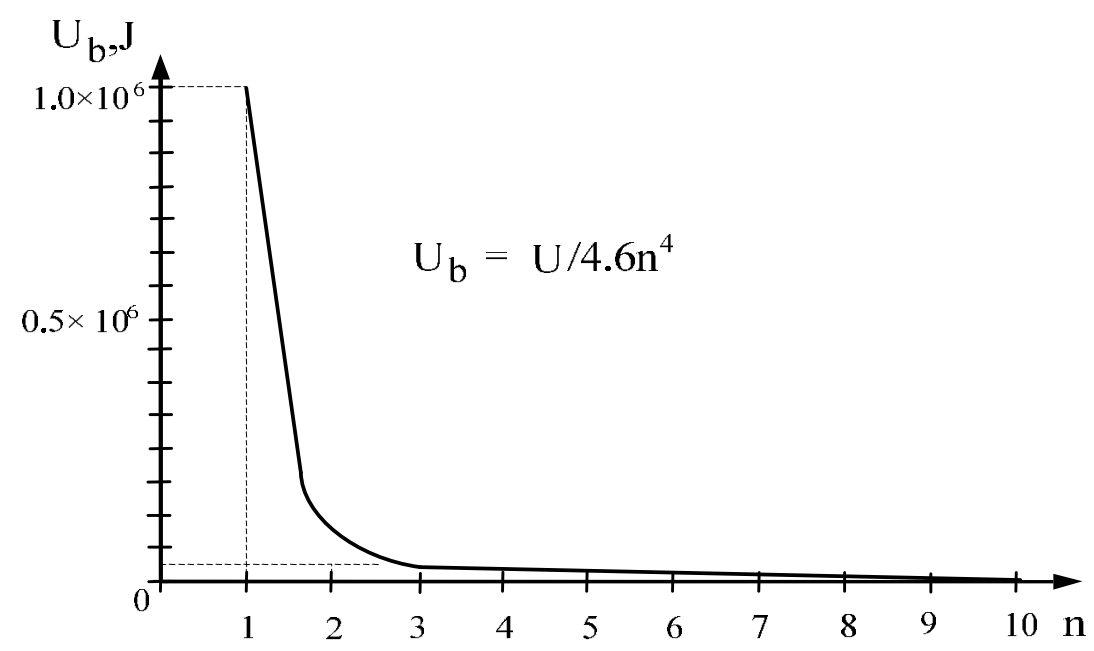

Fig. 3. Dependence of the potential deformation energy

of the beam $U_{b}$, when transformed into integral, on the number of its runs $n$

Based on this, we can conclude that in the case of a larger number of such supports, the potential deformation energy of the beam (mass) of the beam decreases slowly,while each new support increases proportionally the weight of the reinforcement system and adds to the cost of structures and increases the complexity of manufacture and installation.

The second method of calculated SDS regulation in the stiffening beam of the combined system is to create reference points on the extreme supports, what are the opposite actions from the external load (Fig. 4).

At an inclined load on the stiffening beam in its fixed support there will be a horizontal component of the support reaction, which will have a shoulder $e=h / 2$. As a result, there will be a moment in the 
beam, which can not always be neglected (Fig. 4,a). The second option - the movable support of the stiffening beam can have an inclination of a certain angle $\alpha$, up to $90^{\circ}$. After all, then, even in the case of traditional vertical loading, a longitudinal force arises in the beam. Such a beam becomes a spacer structure, the design scheme of which is shown in Fig. $4, b$.
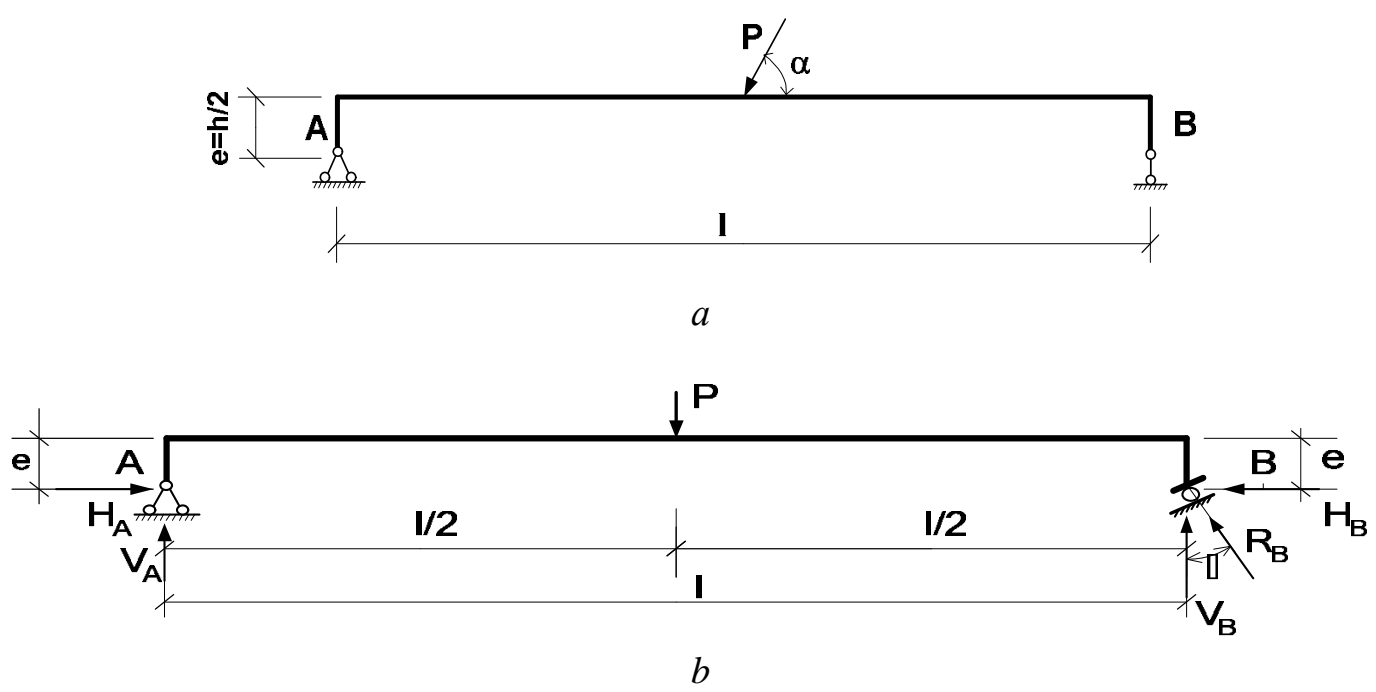

Fig. 4. Calculation scheme: a-beams of rigidity of the truss on two supports; $b$-spacer beam stiffness of the truss

We propose to adjust the SDS of the structure using two parameters $-\mathrm{h}$ (e) and $\alpha$,which significantly expands the scope of this method of SDS regulation of such combined structures (trusses).

The third method of calculated SDS regulation in the stiffness beam of the combined system is the use of inclined supports (Fig. 5).The payload applied to the beam resting on the inclined supports causes the lower belt clamping force or strut to appear.At the same time, the beam is reinforced inside the girder with a sprung, which can be anchored both on the columns of the frame and in other elements of the structure (for example, load-bearing walls) (Fig. 5), and the design scheme of such a combined spacer sprung-beam girder structure is presented in the form of a continuous beam with elastic middle supports (Fig. 5). A feature of this structure scheme is the transformation of the plot of moments from monoextreme to polyextreme, which makes it possible to reduce the working material in the middle part of the run and saves up to $12 \%$ of steel (Hohol, 2018).

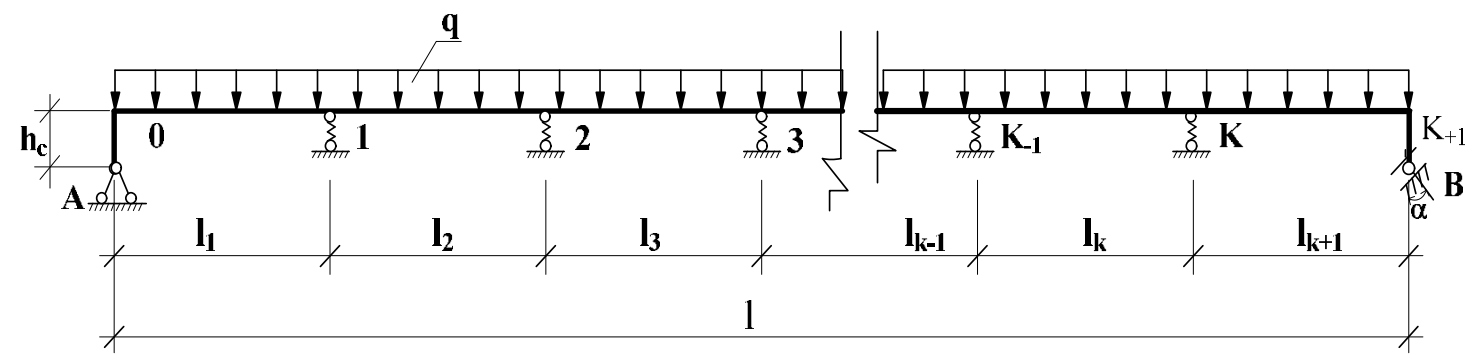

Fig. 5. Physical model for a stiffening beam with an inclined end support and elastic intermediate supports

The fourth method of calculated SDS regulation in the integral rigidity beam of the combined truss system is to take into account the influence of the deformability of the intermediate supports of the rigidity beam on the ratio of support and span moments. Its essence is the alignment of reference and running moments (stresses) along the length of the main element - the stiffening beam (Fig. 6) and obtaining an even stress state in its calculated cross sections. 


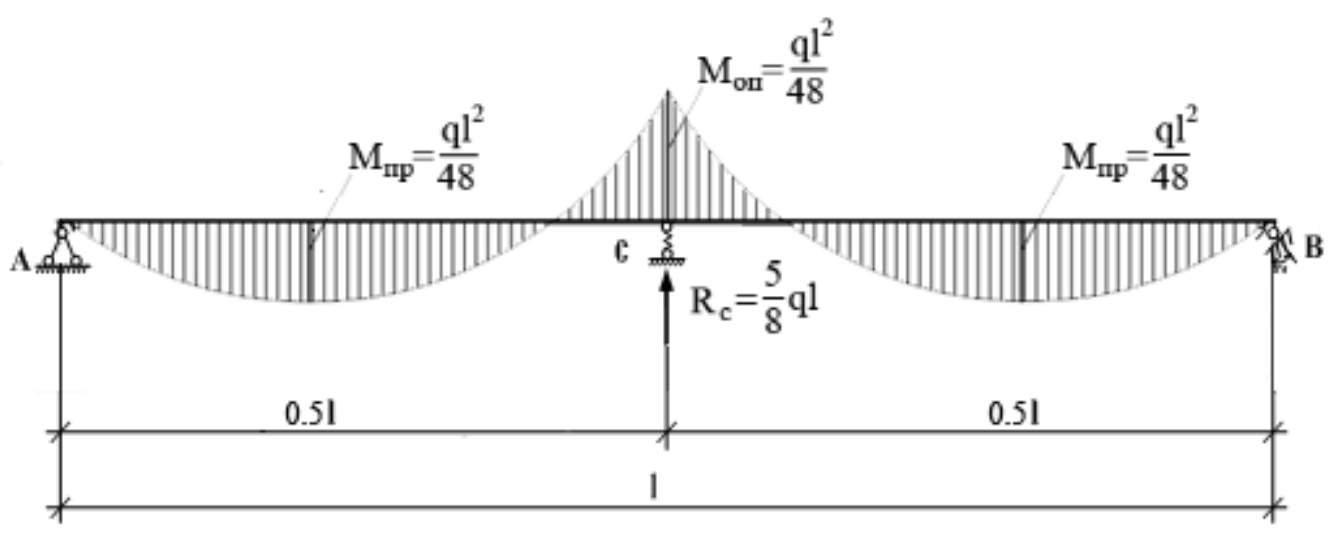

Fig. 6. Equilibrium state of the stiffening beam

In order to establish the feasibility of using the calculation method of SDS regulation in rod structures (for example, combined trusses), a method of qualitative assessment using the coefficients of completeness of the plot of the material (Permyakov et al, 2004).

The following classification is proposed for structural elements. The first class includes elements in which only the longitudinal axial forces act: cables, straps, puffs, suspensions, centrally compressed rods, elements of lattice structures. To qualitatively estimate the stress state of the element, we introduce the concept of the coefficient of completeness of the stress state $\mathrm{k}_{\mathrm{ce}}$. We formulate this concept as follows: the coefficient of completeness of the stress state of the element $\mathrm{k}_{\mathrm{ce}}$ is the ratio of the number of sections $\mathrm{n}_{1}$, in which under the action of load there are $\sigma_{\max } \approx \mathrm{Ry}$, to the length of the element $l$ in meters,

$$
k_{c e}=n_{1} / l \text {. }
$$

Obviously, in the elements in question, we have $n_{1}=l$, ie $\mathrm{k}_{\mathrm{ce}}=1$.

The second class includes elements in which there are only variable in size bending moments these are beam structures.Therefore, we can only talk about the conditional coefficient of completeness of the stress state of the elementk $\mathrm{k}_{\text {cce. }}$ Values of $\mathrm{M}_{\max }$ occur only in one section along the length of the element, ie here we have $n_{1}=1$. Therefore, for such elements we obtain

$$
k_{c c e}=1 / l \text {. }
$$

The third class includes elements in which there are only longitudinal extracentric forces structural elements (eg, frames). For structures consisting of structural elements, the coefficient of completeness of the stress state $\mathrm{k}_{\text {cce }}$ is formulated as follows:the coefficient of completeness of the stress state of structures $\mathrm{k}_{c c e}$ is the ratio of the number of structural elements $\mathrm{n}_{1}$, in which $k_{c e}=1$, to the total number of structural elements.In this formulation, the coefficient of completeness of the stress state $k_{\text {cce }}$ can be equal to one only in homogeneous structures, which are lattice structures, ie trusses and lattice columns.

In order to quantify the possible effectiveness of the calculation method of SDS regulation in rod structures (for example, combined trusses), it is proposed to estimate their SDS by the value of the maximum potential energy. To do this, on the basis of classical (Shmukler, 2017) expressions for potential energy obtained approximate expressions for the maximum potential energy of deformation, which corresponds to the uniform state of the rods of the structure:

for stretched rods

for compressed elements

$$
\frac{A_{i} R_{y, i}^{2} l_{i}}{2 E_{i}}=U s
$$

$$
\frac{\varphi_{i}^{2} A_{i} R_{y, i}^{2} l_{i}}{2 E_{i}}=U \mathrm{c}
$$


for compressed-bent elements of the upper belt of the combined truss with parallel belts

$$
\frac{A_{i} l_{i}}{2 E_{i}}\left(\frac{2 \rho_{i} R_{i, 2}^{2}}{h_{i}}+\varphi_{i}^{2} R_{i, 1}^{2}\right)=U \mathrm{c} 3
$$

where $i$ - is the number of the rod; $l_{i}$ - is the length of the rod; $E_{\mathrm{i}}$ - modulus of elasticity; $R_{y, i}-$ calculated resistance; $A_{i}, \rho_{i}, h_{i}$ - area, core distance and height of the cross section of the rod, respectively; $\varphi_{i}-$ coefficient of stability under central compression; $R_{(i, 1)}, R_{(i, 2)}$ - are determined by formulas (7), (8), respectively.

$$
\begin{gathered}
R_{i, 1}=\frac{i}{\varphi_{i} A_{i}}, \\
R_{i, 2}=R_{y, i}-R_{i, 1},
\end{gathered}
$$

where $N_{i}$ - forces in the elements of the stiffening beam.

To confirm the possibility of applying the proposed indicator, we present the data for calculating the maximum potential deformation energy of two identical sprung beams (Table 1).

\begin{tabular}{|c|c|c|c|c|}
\hline \multirow{2}{*}{$\begin{array}{c}\text { Construction } \\
\text { (placement of sprung) }\end{array}$} & \multicolumn{4}{|c|}{ Maximum potential energy, J } \\
\hline & $\begin{array}{c}\mathrm{U}_{\mathrm{sb}}(\text { stiffness } \\
\text { beams })\end{array}$ & $\mathrm{U}_{\mathrm{s}}(\mathrm{puffs})$ & $\mathrm{U}_{\mathrm{c}}(\mathrm{racks})$ & Total energy \\
\hline & 2543.598 & 4411.356 & 38.081 & 6993.030 \\
\hline & 2543.598 & 423.932 & 59.800 & 3027.330 \\
\hline
\end{tabular}

Table 1

Maximum potential energy of sprung beams

The structures have got one rack, run $9 \mathrm{~m}$ and a height of $0.9 \mathrm{~m}$, but with different placement of the sprung - above and below the stiffening beam, on an evenly distributed load $q=12.75 \mathrm{kN} / \mathrm{m}$. According to the results of the calculation, the beams meet the requirements of the norms, have the same mass $(261.4 \mathrm{~kg}$ ), the same geometric dimensions, but different topology.

According to table. 1 greater is the maximum potential deformation energy of the structure with the placement of the sprung beam below the stiffening beam,indicating the presence in the structure with such a topology of large reserves of bearing capacity,and aboutthat its consideration should be given priority in the first place. This coincides with the well-known fact of the effectiveness of the lower placement of the sprung beams.

Therefore, on the example of a simple combined structures, the possibility of using a quantitative criterion of quality of combined structures with the calculated regulation of SDS is confirmed - their maximum potential deformation energy (Madrazo-Aguirre et al, 2015). Of course, further research is needed in this direction in order to further substantiate this indicator.

\section{Conclusions}

The calculated method of SDS regulation in combined steel trusses makes it possible to reduce steel costs by up to $34 \%$. 
Methods of calculated SDS regulation in the beam of rigidity of the combined system and their rational parameters are offered.

In order to establish the feasibility of using the calculation method of SDS regulation in combined rod structures, a method of qualitative assessment using the coefficients of completeness of the plot of the material is proposed. They make it possible to assess the qualitative volumetric stress state of both structural elements and structures in which these elements are included.

The use of maximum potential energy as a quantitative assessment of the quality of combined structures for the estimated regulation of SDS is proposed.

\section{References}

Hohol, M. V. (2018). Tension regulation in steel combined structures [monograph]. Kyiv: Stal(in Ukrainian).

Hohol, M. V. (2014). Calculation and rational design combined metal structures.Modern industrial and civil construction. (Vol. 10, p. 79-90). Makiivka: DonNACEA (in Ukrainian).

Hohol, M. V., Ordon-Beska, B. (2015). Reduction of material consumption of combined metal structures. Budownictwo o zoptymalizowanym potencjale energetycznym, 1(15), 61-69 (in Russian).

Gogol, M., Zygun, A., Maksiuta, N. (2018). New effective combined steel structures. International Journal of Engineering and Technology. (Vol 7, pp. 343-348). DOI:10.14419/ijet.v7i3.2.14432

Permyakov, V. O., Hohol, M. V., (2004). The problem of regulating the stress-strainstate of flat rod metal structures. Theory and Building Practice, 495, 154-157 (in Ukrainian).

Permyakov, V. O., Hohol, M. V., \& Peleshlo, I. D. (2007). Combined metal structures with regulation and their optimization. International scientific and practical conference Science and Innovations in Modern Construction (p. 17-19), (in Russian).

Shymanovskiy, O. V., Hohol, M. V., (2018). New approach to effective steel combine truss design. $1^{\text {st }}$ International Scientific and Practical Conference Technology, Engineering and Science - 2018. London, United Kingdom, (p. 16-18).

Yuriev, A. (2013). Variational formulations of structural synthesis problems. Collection of scientific papers Sworld 4(14), 67-70 (in Russian).

Ruiz-Teran, A., Aparicio, A. (2010). Developments in under-deck and combined cable-stayed bridges. Bridge engineering, 163, 67-78 https://doi.org/10.1680/bren.2010.163.2.67

Lavrinenko, L., Zotina, A. (2019). Effective parameters of low-element sprung trusses with the use of Ibeams with corrugated walls. Building structures. Theory and practice, 4, 56-69 https://doi.org/10.32347/25224182.4.2019.56-59

Madrazo-Aguirre, F., Wadee, M., Ruiz-Teran, A. (2015). Non-linear stability of under-deck cable-stayed bridge decks. International Journal of Non-Linear Mechanics 77, 28-40 https://dx.doi.org/10.1016/ j.ijnonlinmec.2015.07.001

Bendsoe, M., Sigmund, O. (2003). Topology Optimization. Theory, Methods and Applications. Springer Verlag, Berlin Heidelberg https://doi.org/10.1007/978-3-662-05086-6

Amir, O., Mass, Y., (2016). Topology optimization for staged construction with applications to additive manufacturing, Environmental Engineering, The European Conference on Computational Optimization, EUCCO 2016. Leuven, Belgium

Shmukler, V. S., (2017). New energy principles of rationalization of structures. Collection of scientific works of the Ukrainian State University of Railway Transport, 167, 54-69.

Ruiz-Teran, A. M., \& Aparicio, A. C. (2008). Structural behaviour and design criteria of under-deck cable-stayed bridges and combined cable-stayed bridges. Part 1: Single-span bridges. Canadian Journal of Civil Engineering, 35(9), 938-950. doi.org/10.1139/L08-033 
М. В. Гоголь, І. Д. Пелешко, О. В. Петренко, Д. П. Сидорак

Національний університет "Львівська політехніка", кафедра будівельного виробництва

\section{АНАЛІЗ РОЗРАХУНКОВИХ МЕТОДІВ РЕГУЛЮВАННЯ У СТАЛЕВИХ КОМБІНОВАНИХ ФЕРМАХ}

\section{(С) Гоголь М. В., Пелешко І. Д., Петренко О. В., Сидорак Д. П., 2021}

Розглянуто розрахункове регулювання напружено-деформованого стану (НДС) комбінованих сталевих ферм, яке дає змогу зменшити розрахункові зусилля у деяких елементах (перерізах) конструкції за рахунок збільшення зусиль у інших елементах (перерізах) та спроектувати рівномірно напружені конструкції як найраціональніші системи. Показано, що розрахунковий метод регулювання НДС у комбінованих сталевих фермах дає змогу зменшити витрату сталі до 34 \%. Запропоновано чотири методи розрахункового регулювання НДС в балці жорсткості комбінованої системи та їх раціональні параметри. Наведено переваги комбінованих конструкцій: концентрація матеріалу та можливість проектування їх як малоелементних, що, зокрема, підвищує технологічність.

Подано коефіцієнти повноти напруженого стану конструктивнихелементів, які дають змогу оцінити якісно об’ємний напружений стан конструктивних елементів та конструкцій, у які ці елементи входять.

Виконано порівняльний розрахунок двох комбінованих сталевих ферм із різною топологією, розташуванням конструктивних елементів та однаковою масою і геометричними характеристиками. Здійснено порівняльний аналіз параметрів розрахованих ферм, таких як маса та потенційна енергія деформації. Показано на прикладі, що для кількісного критерію оцінювання якості комбінованих конструкцій з регулюванням НДС можливо раціонально використовувати максимальну потенційну енергію деформації. Наведено залежності для розрахунку максимальної потенціальної енергії стиснених, розтягнутих і стиснуто-зігнутих елементів несучих сталевих конструкцій.

Ключові слова: комбінована сталева ферма, напружено-деформований стан, раціональне проектування, розрахункові методи регулювання, повнота напруженого стану, кількісний критерій оцінки якості, максимум потенційної енергії. 